International Journal of Engineering \& Technology, $7(2.29)(2018)$ 1006-1009
International Journal of Engineering \& Technology
SPC
Website: www.sciencepubco.com/index.php/IJET
Research paper

\title{
The Flipped-Blended Model for STEM Education to Improve Students' Performances
}

\author{
Basuki Wibawa $^{1 *}$, Seipah Kardipah ${ }^{2}$ \\ ${ }^{1,2}$ Universitas Negeri Jakarta \\ *Corresponding Author E-Mail: Bwibawa@Unj.Ac.Id
}

\begin{abstract}
Flipped-Blended model, a combination of flipped classroom and blended learning environment, has become increasingly popular, especially in K-12 education. Flipped-Blended model takes advantage of technology for a more flexible learning environment and facilitates a more learner-centered as well as a more active learning in classroom. Flipped-Blended can be seen as an innovation and a new learning paradigm. This is more than just flipped the in-class and out-class activities, the flipped-blended also change the passive learning into active learning. This model can work well for STEM education due to its active learning and learner-centered nature. Thus, students can explore themselves in class by doing lab work or doing research in small group or individuals. Research method used was a descriptive method. This conceptual paper describes many of the characteristics of flipped-blended model and STEM education. The paper concludes by proposing a flipped-blended theoretical model and offers recommendation regarding implementation in STEM Education.
\end{abstract}

Keywords: Flipped-Blended; STEM Education; Active Learning; Student-Centered

\section{Introduction}

Former President of The United State, Barack Obama, once announced the Department of Education of USA's grant competition to drive innovation in higher education which includes active learning approaches to increase learning and improve student persistence in STEM subjects. This is an important step forward in meeting the President's goal to prepare 1 million college STEM graduates in science, technology, engineering, and mathematics [1]. STEM education is vital to our future, the future of our country, the future of our region and the future of our children. STEM is important, because it pervades every aspect of our lives. Science is about our natural world, the diversity of nature, animals, plants and food, and the list is almost endless. Technology means computers and smart phones, but it goes back to television, radio, microscopes, telegraph, telescopes, the compass, and even the first wheel. Engineering designs roads, buildings, and bridges, but it also tackles today's challenges of transportation, global warming and environment-friendly machines, appliances and systems. We encounter mathematics at the grocery store, the bank, on tax forms, in dealing with investments and the family budget [2]. For our region, investing in the future of science, technology, engineering and mathematics makes sense for small and large technology firms as well as life sciences industry[3]. If the United States is to maintain its global leadership and competitive position, then South East Asia has to motivate its most promising students into the STEM fields. Science has been identified as a national priority, but science teachers can't do it all on their own. Parents, community and policy makers have to become more interested and knowledgeable about the STEM education.

On the other hand, many literatures on the flipped classroom have been reviewed. It is believed that flipped classroom has gained great attention of many researchers as a result of what educators are implementing at their classrooms. Flipped classroom along with blended learning environment which includes online learning is worthy enough to be further studied. The main objective of the paper is proposing a flipped-blended theoretical model that can be implemented in STEM education.

\section{Literature Review}

\subsection{The Flipped Classroom and Blended Learning}

"Flipping the classroom" means that activities that have traditionally taken place inside the classroom now take place outside the classroom and vice versa [4]. In traditional classrooms, students listen to a lecture and subsequently complete required assignments after the lecture. Lecturing may lure students into a ritual of memorizing information as preparation for the examination [5]. Teachers who flip a lesson can assign a small group or individual activities in class, freeing up time to monitor student progress, check for understanding, and provide feedback and assistance when necessary. Essentially, the classroom experience becomes much more focused on student processing and the development of ideas, moving away from students as passive receivers of information[6].

The idea of flipping the classroom has recently gained prominence due to advances in technology and increased ubiquitous access to computers and other mobile devices [7]. Students now can learn through online learning where they can take control over time, place, and pace. Blended learning is a formal education program in which a student learns at least in part through online learning and at least in part at a supervised brick-and-mortar location away from home [8]. A blended course requires an online learning environment to organize and supplement the onsite sessions. The online environment may be a simple website combined with email or discussion [9]. 
Flipped classroom and blended learning environment can result an improvement in students' performance if it is designed and conduct well. In a flipped-blended model, students listen the lecture out class through online learning and perform the traditional homework, lab, and research paper activities in class with assistance of the instructor. Thus, by flipping the classroom, it also flipped Bloom's taxonomy of learning, a pyramid of learning domains in a hierarchical framework from simple to complex. The out of class, online, passive learning, comprised the reading materials, watching recorded lectures, remembering definitions and equations also confirming the understanding of content and recall of information then followed by in class, active learning, with quizzes to assess understanding and calculation of dosing regiments [10]. According to Schneider et al.,[10], as student progressed to higher levels of learning, they applied their knowledge to evaluate and analyze different problems or scenarios and involved in the discussion of concepts. Students then demonstrated higher order thinking skills as they synthesized technical and medical information to create easy-to-read resources.

\subsection{Rationale for Implementing Flipped-Blended Model}

The main goal of a flipped-blended model is to enhance student learning and improve student's performance by reversing the traditional model of a classroom, focusing class time on student understanding rather than on lecture. There are numerous potential advantages to this model.

Flipped-blended model, which adopt the flipped classroom methods, can helps busy students, helps struggling students, helps students of all ability to excel, and allows students to pause and rewind the lecture $[11,12]$. Flipping the classroom provides a great deal of flexibility to help students with their busy lives and provides more time for teacher to walking around helping students who struggle most. It also helps students with special needs in which they can watch the videos as many times as they need to learn the material. Students can pause and rewind the lecture and make sure they actually learn the important concepts.

Flipped-blended also offers more interactions of students, teachers, and contents. In a blended learning environment, students can watch the lecture online and start a discussion online anytime they need help or feel confuse. In this way, flipped-blended enhance student[s]-student[s] interaction, student[s]-content[s] and stu$\operatorname{dent}[\mathrm{s}]$-teacher[s] interaction online. These interactions getting better in classroom because in a flipped-blended, teacher has more time to get close with their student, assist and help them whenever they feel confuse or not sure.

Flipped-blended also rely on the concept of experiential learning, which is notably attributed to Dewey. Kolb later promoted a learning cycle model that theorizes that most effective learning occurs when knowledge is created via experience. Flippedblended provide provides students with the opportunity to put what they are learning into action in the classroom beyond through lived interactive experience. These will also involves active learning which place responsibility for learning on the student and requires that learners do much more than just listen to an instructor lecture [13].

The most recent and rigorous evidence to support active learning comes from a meta-analysis that compared 225 studies of learning using traditional lecture methods to 158 studies using active-learning techniques in the STEM disciplines. Results demonstrated that students in the courses taught with active learning had increased exam scores and concept inventories and were 1.5 times less likely to fail than those in the traditionally taught courses. Additional evidence that active learning as a method of instruction increases student engagement and promotes academic achievement and positive student attitudes is abundant and comes from many disciplines [13]. Flipped-blended can therefore be worth implementing for three important reasons: flexibility, student-teacher interaction and active learning.

\subsection{STEM Education}

STEM stands for Science, Technology, Engineering, and Mathematics. STEM education was originally called Science, Mathematics, Engineering and Technology [SMET], and was an initiative created by the National Science Foundation [NSF] to provide all students with critical thinking skills that would make them creative problem solvers and ultimately more marketable in the workforce [14]. Science, technology, engineering, and mathematics are cultural achievements that reflect people's humanity, power the economy, and constitute fundamental aspect of our lives as citizens, workers, consumers, and parents. An increasing number of jobs at all levels, not just for professional scientists, require knowledge of STEM. In addition, individual and societal decisions increasingly require some understanding of STEM, from comprehending medical diagnoses to evaluating competing claims about the environment to managing daily activities with a wide variety of computer-based application [15]

In 2015, the U.S. Department of Education, in collaboration with American Institutes for Research [AIR], convened a series of 1.5day workshops that brought together invited experts and thought leaders in science, technology, engineering, and mathematics [STEM] teaching and learning to share their ideas and recommendations for an innovative future of STEM education. There were six interconnected components resulted from the workshops, as follows: engaged and networked communities of practice, accessible learning activities that invites intentional play and risk, educational experiences that include interdisciplinary approaches to solving "grand challenges", flexible and inclusive learning space supported by innovative technologies, innovative and accessible measures of learning, and societal and cultural images and environments that promote diversity and opportunity in STEM [16]. The report of the workshops also mentioned about the opportunity to create more flexible and inclusive learning space using flipped classroom approaches and technology-enabled tools.

\subsection{Flipped-Blended Theoretical Model}

The flipping model is an outgrowth of various pedagogical movements in recent years that seek to minimize the amount of time that students spend passively listening to lectures presented by their teachers and to maximize the amount of class time that they spend actively learning material through activities designed to accommodate a broad range of learning styles and to promote deep learning [13]. As for STEM education, flipped-blended is a new learning paradigm, an innovation and for improving student's performance. The flipped-blended theoretical model [Figure 1] in this paper is based on several tenets as follows:

- Both experience and the conveyance of information are important for learning [17].

- Online learning for out class activities.

- A more active learning in class activities.

- Teacher assist, assess, and motivate students in flippedblended learning environment.

- $\quad$ Teacher develops the flipped-blended instructional model and implements it.

- $\quad$ Flipped-blended model also turn up side down the bloom taxonomy

Dewey argued that learning begins with experience. By giving primacy to students' experience in classroom instruction, teachers help students move from what came before to what is to come. It is the instructor's task to attend to the direction in which students' experience is heading and to shape it so that students are not just "doing things" but are able to "get the idea of" what they are doing. This is accomplished when students conceptualize aspects of what they are doing and make specific ties between those conceptions and their experiences. Dewey's theory shows the critical importance of effectively structuring the interaction between an out-of-class conveyance of information and the in-class experiences of the students during flipped instruction. Dewey expressed it in this way, "harmful as a substitute for experience, [conveyance 
of content] is all-important in interpreting and expanding experience" [17].

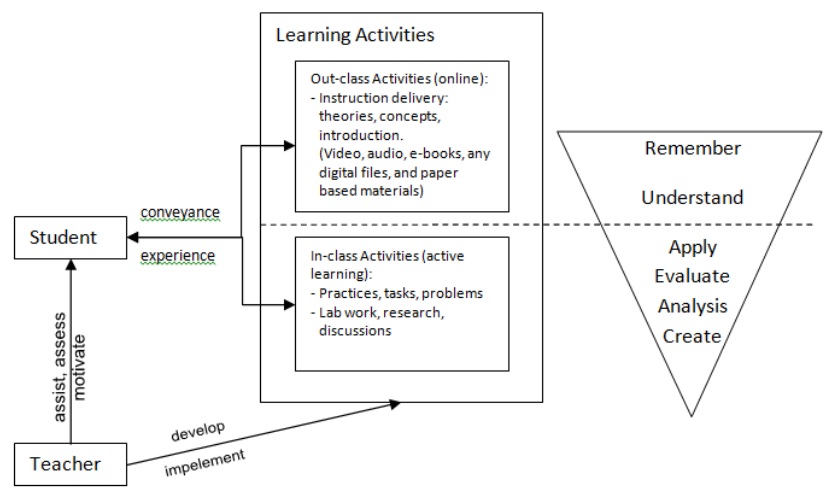

Fig. 1: Flipped-blended Theoretical Model

There are in class and out class activities in flipped-blended model. The flipped-blended provides two forums for such students to work together - at home and at school. In other words, through the use of technology, even at-home learning experiences can occur within a collaborative environment [6]. While, in class activities teachers who flip a lesson can assign small group or individual activities in class, freeing up time to monitor student progress, check for understanding, and provide feedback and assistance when necessary. Essentially, the classroom experience becomes much more focused on student processing and the development of ideas, moving away from students as passive receivers of information [6]. The underlying principles of classroom flipping are supported by theories of active learning and are the same regardless of the subject matter taught. Adjustments to the approach can easily be made to fit particular teaching contexts and strategies. Some of the major issues and trends found in the literature were related to feedback from students on their experiences in the flipped courses [18].

In a flipped-blended learning, teachers assist students doing their tasks or problems. Teacher provide solution every time student found difficulty when doing the tasks in other words teacher can give struggling students ample attention and assessment to meet their needs Teacher also able to assess all students individually. When students realize that the learning is what is being evaluated and not whether they completed a checklist of items, they feel empowered to take control of their own learning [19]. Teacher then have the flexibility to give alternate assessments on an individualized level and talk to students and help them where they are struggling. If they are behind grade level, teacher can easily modify assignments or teach/ reteach missing content [19].

Students who are motivated to learn something use higher cognitive processes in learning about it. Motivation to do something can come about in many ways. It can be a personality characteristic or a stable long-lasting interest in something. There are several theories of motivation that exist. Some state that motivation is tied to the idea that behaviours that have been rewarded in the past will be more likely to be repeated in the future. Therefore past experiences will motivate a student to perform in future ones [20]. Bowdon, Mansfield, and Waldrop recommended using low-stakes assignments to motivate students to stay on track with their preparation for the course and to allow them to conduct ongoing assessment of their own progress [21].

Instructional should be developed before being implemented. Strategies for moving the lecture out of the classroom include: selecting what course content you want students to cover outside of class in place of the traditional lecture, deciding how you want that content organized, choosing what media to use to deliver that content to students outside of class, creating or gathering the learning materials, and then making the materials available for students to access outside of class [18].

There are few recommendations regarding its implementation as follows. In order to make it work, instruction in STEM Education must properly designed. Rule of games should have been set, learning materials should have been prepared, and instructional goals should already been determined before teacher deliver it. The design has to be clear and detail because it will guide the teacher and students to the whole learning process. The design should include the goals, the instructional analysis, the instructional strategies, the learning media, and the assessments. Moreover, flipped-blended is not just about inverting the in-class and out-class activities. It also flipped the passive learning in the classroom into active learning with more tasks and exercises. So the teacher must prepare various activities which cause students to learn actively. For example, teacher can have a competition or quiz to motivate students. Motivation is essential for flippedblended learning. Students should be reassured that they can learn independently outside the classroom. Thus, learning materials should be designed to enable students learning outside the classroom. Teachers also have to be available, to be always there to help and guide students. Teachers must be reachable in all online activities as well as in-class activities. Although the emphasis of the in-class activities is the provision of tasks and exercises, it should not be forgotten that teachers should also ensure that students understand the concept of what they are doing. So they are not just good at doing it [how to do it], but also understand why they have do it.

\section{Conclusion}

In the flipped-blended model, the learning activities of students are inverted, students review lecture materials outside of class and then come to class to be involved in learning activities that are active with the assistance of their teachers. Flipped-blended learning also promotes online learning and active learning. These approaches, where students gain content and technical knowledge through online videos outside of the school day to prepare them for more active, applied learning of the content in the classroom, and other technology advancements can improve students' performance in STEM education. The flipped-blended can be seen as an innovation in increasing student achievement, improving student motivation, providing more time in the classroom for educators and students to ask higher order questions and receive on the spot feedback. Future research can be focus on how to plan and design an instructional model of flipped-blended that comprises what Bloom's taxonomy struggles for in education and how teachers can use the newly freed class-time that is offered by flippedblended.

\section{References}

[1] Handelsman J, Drosback M. Driving Innovation in STEM Education: The White House. 2015.

[2] SciencePioneer. Why STEM Education Is Important For Everyone 2015 [Available from: http://www.sciencepioneers.org/parents/why-stem-is-important-toeveryone.

[3] Qureshi MI, Janjua SY, Zaman K, Lodhi MS, Tariq YB. Internationalization of higher education institutions: implementation of DMAIC cycle. Scientometrics. 2014;98[3]:2295-310.

[4] Lage MJ, Platt GJ, Treglia M. Inverting the classroom: A gateway to creating an inclusive learning environment. The Journal of Economic Education. 2000;31[1]:30-43.

[5] Rotellar C, Cain J. Research, perspectives, and recommendations on implementing the flipped classroom. American journal of pharmaceutical education. 2016;80[2]:34

[6] Carbaugh EM, Doubet KJ. The Differentiated Flipped Classroom: A Practical Guide to Digital Learning. Thousand Oaks: Corwin; 2016.

[7] Davies RS, Dean DL, Ball N. Flipping the classroom and instructional technology integration in a college-level information systems spreadsheet course. Educational Technology Research and Development. 2013;61[4]:563-80.

[8] Horn MB, Staker H. Blended: Using disruptive innovation to improve schools: John Wiley \& Sons; 2014.

[9] Stein J, Graham CR. Essentials for blended learning: A standardsbased guide: Routledge; 2014. 
[10] Schneider J, Munro I, Krishnan S. Flipping the classroom for pharmacokinetics. American journal of educational research. 2014;2[12]:1225-9.

[11]Bergmann J, Sams A. Flip your classroom: Reach every student in every class every day: International Society for Technology in Education; 2012.

[12] Cockrum T. Flipping your English class to reach all learners: Strategies and lesson plans: Routledge; 2013.

[13] Saitta E, Morrison B, Waldrop J, Bowdon M. Introduction: joining the flippedclassroom conversation. Best practices for flipping thecollege classroom Routledge, New York. 2016.

[14] White DW. What is STEM education and why is it important Florida Association of Teacher Educators Journal. 2014;1[14]:1-9.

[15]Council NR. Successful K-12 STEM education: Identifying effective approaches in science, technology, engineering, and mathematics: National Academies Press; 2011.

[16] The U.S. Department of Education, Office of Innovation and Improvement. STEM 2026: A Vision for Innovation in STEM Education. Washington, DC: The U.S. Department of Education; 2016.

[17] Strayer JF, Hart JB, Bleiler-Baxter SK. Kick-starting discussions with the flipped classroom. Mathematics Teacher. 2016;109[9]:662-8.

[18]Hughes H. Flipping the College Classroom: Participatory Learning, Technology, and Design. In: Kyei-Blankson L, \& Ntuli, E., editor. Practical Applications and Experiences in K-20 Blended Learning Environments. Hersey: Information Science Reference; 2014.

[19] Cockrum T. Flipping Your English Class to Reach All Learners Strategies and Lesson Plans. New York: Taylor and Francis; 2014.

[20]Wiseman DG, Hunt GH. Best Practice in Motivation and Management in The Classroom. Illinois: Charles C Thomas Publisher; 2014.

[21] Bowdon MA, Mansfield LP, Waldrop JB. Reflecting on the Flipping Experience. In: Waldrop J. B B, M. A., editor. Best Practices for Flipping the College Classroom. New York: Routledge; 2016. 